\title{
The conservation of native priority medicinal plants in a Caatinga area in Ceará, northeastern Brazil
}

\author{
MARIA O. SANTOS, BIANCA V. DE ALMEIDA, DAIANY A. RIBEIRO, DELMACIA G. DE MACÊDO, \\ MÁRCIA J.F. MACÊDO, JULIMERY G.F. MACEDO, FRANCISCA F.S. DE SOUSA, LIANA G.S. DE \\ OLIVEIRA, MANUELE E. SARAIVA, THATIANE M.S. ARAÚJO and MARTA M.A. SOUZA \\ Universidade Regional do Cariri, Departamento de Biologia, Laboratório de Ecologia Vegetal, Centro de \\ Ciências Biológicas e da Saúde, Rua Cel. Antônio Luiz, 1161, Pimenta, 63105-000 Crato, CE, Brazil
}

Manuscript received on September 29, 2016; accepted for publication on February 10, 2017

\begin{abstract}
Much of the Brazilian semiarid region faces a considerable process of degradation of natural resources, and ethnobotanical studies have collaborated with important information about the use and traditional knowledge, serving as a tool to design conservation strategies of native plant species. Thus, this study aimed to determine medicinal species meriting conservation priorities in a "Caatinga" area in the northeastern of Brazilian territory. The ethnobotanical data were collected through semi-structured interviews with key subjects selected through the "snowball" technique. The availability and species conservation priority was verified by relative density, risk of collection, local use and use of diversity in the forest fragment sampled. It was recorded 42 native medicinal plants and conservation priority score was calculated for seven species, including Mimosa tenuiflora, Hymenaea courbaril, Ximenia americana and Amburana cearensis need immediate conservation and attention, since their collection does not occur in a sustainable way. In order to ensure the perpetuation of the species and the sustainability of traditional therapeutic practice there needs to be a development of conservation practices of caatinga remaining to better conserve the species of the biome.
\end{abstract}

Key words: availability, biodiversity conservation, therapeutic practices.

\section{INTRODUCTION}

In recent years, many studies have been intensified focused on medicinal plants (Souza et al. 2013, Ribeiro et al. 2014a) and ethnobotany has been highlighted in the evaluation of traditional therapies and the development of strategies for the conservation of medicinal flora through local practices (Oliveira et al. 2007, Albuquerque et

Correspondence to: Maria de Oliveira Santos

E-mail: maria.s.oliveira@live.com al. 2011). Approximately $25 \%$ of pharmaceutical drugs are chemicals derived from vegetable, where $85 \%$ of the population uses traditional systems herbal healing, increasing the use and exploitation of biodiversity every day (Oliveira 2010).

Excessive collection of this feature can affect plant populations modifying their structure, thus, changing the dynamics of the same over time and in terms of individual, affecting their growth and reproductive capacity (Shahabuddin and 
Prasad 2004), may cause natural and sometimes irreversible losses. However, recovery strategies can be developed and conservation of these areas from surveys of the potential of plant resources available to a particular community (Roque et al. 2010)

Brazil, which is the country holder of one of the greatest biodiversity in the world, has among its biomes, the caatinga, as one of the most exploited and threatened that needs, given the conditions, recommendations and strategies for conservation of natural resources (Albuquerque et al. 2011), for the misuse of caatinga resources have caused irreversible damage to the process of desertification now affects about $15 \%$ of the area; Predatory extraction and irrecoverable loss of the diversity of flora (Schober 2002).

Current studies show the importance of savanna vegetation for the conservation of Brazilian biodiversity, due to the high level of endemism of the species having the lowest number and the less extent protected from all Brazilian biomes (Leal et al. 2005), due to the increasing waste, caused mainly by human activities on the natural resources available (Albuquerque et al. 2011). Among the many uses of this vegetation are the timber, medicinal and widely referred to forage in ethnobotanical surveys in rural communities. Thus, this study aimed to determine medicinal species meriting conservation priorities in a caatinga area in northeastern Brazil.

\section{MATERIALS AND METHODS}

\section{STUDY AREA}

The survey was conducted in Nazareth community, next to the Legal Reserve of Nazareth Farm, on the banks of the a federal road (BR 116), located $5 \mathrm{~km}$ far from the city of Milagres, between coordinates $7^{\circ} 18$ 'S and $38^{\circ} 56^{\prime}$ ' W (2015), situated in South mesoregion of Ceará state, with an area of 577 square kilometers (IBGE 2010). It makes boundaries with some other cities like Aurora, Barro, Mauriti, Brejo Santo, Abaiara and Missão Velha. It has a hot tropical semiarid climate with annual average temperature of $26^{\circ} \mathrm{C}$. The annual average rainfall is $939 \mathrm{~mm}$, with the rainy season from February to April. The relief includes Araripe and backwoods depression. The soils are mostly litholic, read-yellow podizolic, and Vertisol (IPECE 2015). Its vegetation consists of forest Deciduous Thorny and semi deciduous forest Tropical Rain (IPECE in 2012).

\section{DATA COLLECT}

The ethnobotanical survey was conducted through semi-structured interviews, where knowledge of subjects was granted after reading, permission and signature of informed consent and informed. It is important to mention that this research was submitted to the Research Ethics Committee of the Regional University of Cariri and approved with Opinion No. 019980. Interviews were conducted with $30 \mathrm{key}$ informants and local experts (23 females and 7 males), aged 23-71 years selected by the snowball technique. It was also made some informal interviews with local residents to get information about using wood available species. To assess the local availability of medicinal species in the ethnobotanical survey was selected an area of caatinga apparently kept close to the community studied.

The availability was based on the relative density of species in the forest fragment maintained, obtained through the phytosociological study, which was applied the method of multiple plots for a total of 12 plots of $10 \times 10 \mathrm{~m}$, which included all individuals alive and standing dead with stem diameter at the DNS ground level $\geq 3 \mathrm{~cm}$ and height $\geq 1 \mathrm{~m}$. The analyzed phytosociological parameters were density, dominance and importance value index using the Fitopac 1.0 that characterized the area (Shepherd 1995). 


\section{FLORISTIC SURVEY}

Species that were collected were in reproductive stages with flower and/or fruit, accompanied by duplicates to follow with herborization process. The herborization process occurred in accordance with the standard methods recommended by Mori et al. (1989). The identification was made through specialized bibliography, as compared to previously identified plant material and / or sent to taxonomists. The witness material was incorporated into the collection of the Caririense Dardano de Andrade Lima Herbarium of the Regional University of Cariri (HCDAL-URCA).

\section{DATA ANALYSIS}

\section{Conservation priorities for medicinal plants}

The conservation priority (CP) was performed according to Dzerefos and Witkowski (2001), Oliveira et al. (2007), Albuquerque et al. (2011). Based on the analyzes of phytosociological parameters for the plant community (density), the conservation priority (CP) of the species was calculated, with criteria described in Table I: $\mathrm{CP}=$ 0.5 (BS-biological score) +0.5 (RU-risk of use)

Where: $\mathrm{SB}=\mathrm{D} \times 10$ (score for relative density) $\mathrm{RU}=0.5(\mathrm{H})+0.5(\mathrm{U}) \times 10(\mathrm{H}$ is the risk of colletion, and $U$ is the value of use).

$\mathrm{H}$ (Table I)

$\mathrm{U}=\mathrm{L}($ local importance $)+\mathrm{V}$ (diversity usage $) / 2$

In order to obtain the calculation of the relative density were included living individuals and those who presented partially cut, but with conditions to be yet collected for some utility. The average of the sum of the local importance (L) and the diversity of use (V) determined the value of use (U), which together with the collection risk score $(\mathrm{H})$ provided the risk of use (RU) score. The risk of use score was obtained by the following formula: $\mathrm{RU}=0.5$ $(\mathrm{H})+0.5(\mathrm{U}) \times 10$.
The value of the collection risk $(\mathrm{H})$ was based on the biological consequences of collection according to the removed vegetal part (Table I). The value of the local importance $(\mathrm{L})$ was determined by the percentage of the number of informants who indicated a particular species as medicinal and the diversity of use (V) was based on the number of types of use attributed to a species, varying its score of 1 To 10. Wood usage for some species was associated with the calculations by adding 10 points (Table I).

The score allowed to classify medicinal plants into three categories (Dzerefos and Witkowski 2001): Category 1 : with value $>80$, where species that require high priority conservation controlled collection, associated with the establishment of alternatives are framed; Category 2: where are included the species with between 60 and 80, with the potential to be collected according to the location and specific quotas; Category 3: species obtained value $<60$, includes appropriate species for more intense sampling.

\section{RESULTS AND DISCUSSION}

\section{RICHNESS OF PLANT MEDICINAL, HABITS AND PARTS UTILIZED}

It was recorded 42 native medicinal species belonging to 34 genera and 24 families (Table SI - Supplementary Material). Fabaceae (07 spp.) and Euphorbiaceae (04 spp.) had the largest number of species, and is also commonly found in other ethnobotanical work carried out in areas of caatinga (Cartaxo et al. 2010, Lós et al. 2012, Ribeiro et al. 2013, 2014b), suggesting that representatives of Fabaceae are extremely important for medicinal use and have great potential for bioactive compounds (Moerman and Estabrook 2003), as well as timber and fodder (Almeida et al. 2012).

In the habit of species, the arboreal predominated with $46 \%$, followed by herbaceous $(20 \%)$, scandent (15\%), shrubs (11\%) and subshrub 
TABLE I

Criteria and scores used to calculate priorities conservation of medicinal plants arising of the phytosociological survey in the community Nazaré, Milagres-CE.

\begin{tabular}{|c|c|}
\hline CRITERIA & ESCORES \\
\hline \multicolumn{2}{|l|}{ A. Relative density in the fragment (D) } \\
\hline Non-registered-very low $(0-1)$. & 10 \\
\hline Low $(1<3.5)$. & 7 \\
\hline Medium $(3.5<7)$ & 4 \\
\hline $\operatorname{High}(\geq 7)$ & 1 \\
\hline \multicolumn{2}{|l|}{ B. Risk of collection $(\mathrm{H})$} \\
\hline $\begin{array}{l}\text { Destructive collection of the plant or over-exploitation of roots or bark. Collection represents the removal of the } \\
\text { individual. }\end{array}$ & 10 \\
\hline $\begin{array}{l}\text { Collection of perennial structures such as barks and roots, and collection of part of the stem to extract latex, } \\
\text { without killing the individual. }\end{array}$ & 7 \\
\hline $\begin{array}{l}\text { Collection of perennial aerial structures such as leaves, which may affect the plant's energetic investment, } \\
\text { survival, and reproductive success in the long term. }\end{array}$ & 4 \\
\hline $\begin{array}{l}\text { Collection of transitory structures as flowers and fruits. The regeneration of the population may be altered in the } \\
\text { long term by collecting the seed supply, but the individual itself is not affected. }\end{array}$ & 1 \\
\hline \multicolumn{2}{|l|}{ C. Local use (L) } \\
\hline High (species cited by $>75 \%$ of local informants). & 10 \\
\hline Moderately high ( $50-75 \%$ of local informants). & 7 \\
\hline Moderately low (cited by $25-50 \%$ of local informants) & 4 \\
\hline Very low (cited by $<25 \%$ of local informants) & 1 \\
\hline \multicolumn{2}{|l|}{ D. Diversity of use ( V) } \\
\hline For each type of medicinal use 1 point is added, for a maximum of 10 points. & $1-10$ \\
\hline
\end{tabular}

SOURCE: Albuquerque et al. (2011), modified of Dzerefos and Witkowski 2001.

(8\%). The predominance of arboreal habit becomes indicative of the increasing use of native species for local therapeutic practices. This fact can be justified by the greater willingness of forest resources throughout the year and considerable resistance to sudden changes in the environment, such as the prolonged drought that occurs commonly in the Northeast (Silva and Proença 2008).

Turning attention to the parts of the plant, root stood out with $32.3 \%$ of the use of quotations, then peel and stem bark which together had 38.9\% and sheet with $20.3 \%$, the rest of the plant parts (flower, heart, fruit peel, fruit and latex) amounted to $8.5 \%$. The roots represent the plant parts most used in studies by Marinho et al. (2011), different situation from other studies in caatinga areas that has among its main uses bark and the inner bark of the stem
(Almeida and Albuquerque 2002, Ribeiro et al. 2013).

\section{AVAILABILITY OF MEDICINAL SPECIES}

In a sampled forest fragment was recorded 28 species in 10 families and 24 genera (Table II). Fabaceae (8 spp.) and Euphorbiaceae (4 spp.) were the most representative families in relation to number of species. These families are commonly found in floristic studies, structure and medicinal plant surveys in the caatinga area as having the highest number of species (Sampaio 1996, Figueiredo etal. 1997, Alcoforado-Filho et al. 2003), having medicinal species value (Albuquerque et al. 2009, Roque et al. 2010, Oliveira et al. 2010). A considerable demand for these families for medical 
TABLE II

List of species recorded in survey phytosociological in the Nazaré community, City of Milagres, Ceará, Brazil.

\begin{tabular}{|c|c|c|c|c|c|c|}
\hline Family/ Scientific Name & $\begin{array}{l}\text { Local } \\
\text { Name }\end{array}$ & $\mathbf{N}$ & $\begin{array}{l}\text { RD } \\
(\%)\end{array}$ & $\begin{array}{c}\text { RDO } \\
(\%)\end{array}$ & $\begin{array}{l}\text { RF } \\
(\%)\end{array}$ & IV \\
\hline \multicolumn{7}{|l|}{ ANNONACEAE } \\
\hline Annona leptopetala (R. E. Fr.) H. Rainer & Bananinha & 7 & 1.79 & 0.37 & 2.04 & 4.20 \\
\hline \multicolumn{7}{|l|}{ APOCYNACEAE } \\
\hline Aspidosperma pyrifolium Mart. & Pereiro & 1 & 0.26 & 0.31 & 2.04 & 2.61 \\
\hline \multicolumn{7}{|l|}{ COMBRETACEAE } \\
\hline Thiloa glaucocarpa (Mart.) Eichler & Sipaúba & 162 & 41.33 & 35.70 & 6.12 & 83.15 \\
\hline Combretum mellifluum Eichler & Cipó & 3 & 0.77 & 0.04 & 2.04 & 2.85 \\
\hline \multicolumn{7}{|l|}{ EUPHORBIACEAE } \\
\hline Croton blanchetianus Baill. & Marmeleiro & 33 & 8.42 & 6.80 & 6.12 & 21.34 \\
\hline Cnidoscolus urens (L.) Arthur & Cansanção & 8 & 2.04 & 2.49 & 4.08 & 8.61 \\
\hline Manihot esculenta Crantz & Maniçoba & 4 & 1.02 & 0.10 & 2.04 & 3.16 \\
\hline Sapium glandulosum (L.) Morong & Burra-leiteira & 2 & 0.51 & 0.02 & 2.04 & 2.57 \\
\hline \multicolumn{7}{|l|}{ FABACEAE } \\
\hline $\begin{array}{c}\text { Pityrocarpa moniliformis (Benth.) Luckow \& R. W. } \\
\text { Jobson }\end{array}$ & Carrasco & 28 & 7.14 & 4.25 & 6.12 & 17.51 \\
\hline Bauhinia cheilantha (Bong.) Steud. & Mororó & 18 & 4.59 & 1.16 & 4.08 & 9.83 \\
\hline Hymenaea courbaril L. & Jatobá & 3 & 0.77 & 0.37 & 4.08 & 5.22 \\
\hline Mimosa tenuiflora (Willd.) Poir. & Jurema-preta & 2 & 0.51 & 0.08 & 4.08 & 4.67 \\
\hline Luetzelburgia auriculata (Allemão) Ducke & Pau-mocó & 1 & 0.26 & 0.02 & 2.04 & 2.31 \\
\hline Anadenanthera colubrina (Vell.) Brenan. & Angico & 1 & 0.26 & 0.00 & 2.04 & 2.30 \\
\hline Acacia glomerosa Benth. & Espinheiro & 24 & 6.12 & 1.37 & 4.08 & 11.57 \\
\hline Amburana cearensis (Allemão) A. C. & Imburana-de-cheiro & 2 & 0.51 & 1.09 & 2.04 & 3.64 \\
\hline \multicolumn{7}{|l|}{ MORACEAE } \\
\hline Brosimum gaudichaudii Trécul & Inharé & 6 & 1.53 & 0.27 & 2.04 & 3.84 \\
\hline \multicolumn{7}{|l|}{ MYRTACEAE } \\
\hline Psidium guineense $\mathrm{Sw}$. & Goiabinha & 15 & 3.83 & 7.45 & 6.12 & 17.39 \\
\hline Erytroxylum sp. & Murta & 3 & 0.77 & 3.95 & 4.08 & 8.80 \\
\hline \multicolumn{7}{|l|}{ OLACACEAE } \\
\hline Ximenia americana L. & Ameixa & 3 & 0.77 & 5.41 & 2.04 & 8.22 \\
\hline \multicolumn{7}{|l|}{ RUBIACEAE } \\
\hline Tocoyena formosa (Cham. \&Schltdl.) K. Schum. & Frei-jorge & 4 & 1.02 & 4.63 & 4.08 & 9.73 \\
\hline Randia armata (SW.) DC. & Espinho Judeu & 5 & 1.28 & 2.79 & 4.08 & 8.15 \\
\hline \multicolumn{7}{|l|}{ RUTACEAE } \\
\hline Fagara aculeatissima (Engl.) Engl. & Limãozinho & 3 & 0.77 & 1.07 & 4.08 & 5.92 \\
\hline Pilocarpus spicatus A. St.-Hil. & Jaborandi & 3 & 0.77 & 0.22 & 2.04 & 3.03 \\
\hline \multicolumn{7}{|l|}{ MORPHOSPECIES } \\
\hline Morphospecie 1 & Mão maluco & 11 & 2.81 & 4.86 & 6.12 & 13.79 \\
\hline Morphospecie 2 & Podal & 7 & 1.79 & 0.12 & 2.04 & 3.94 \\
\hline Morphospecie 3 & Violeta & 28 & 7.14 & 14.54 & 2.04 & 23.72 \\
\hline Morphospecie 4 & Undetermined 1 & 2 & 0.51 & 0.35 & 2.04 & 2.90 \\
\hline Dead & & 3 & 0.77 & 0.16 & 4.08 & 5.01 \\
\hline
\end{tabular}

N: Number of individuals; RD: relative density; RDO: relative dominance; RF: relative frequency; IV: importance value; No of sample. 
use may be linked to a wide diversity added the availability of the species in the environment.

The species with high density in the area were Thiloa glaucocarpa totaling $41.33 \%$ of the sampled individuals, followed by Croton blanchetianus (8.42\%), Pityrocarpa moniliformis $(7.14 \%)$ and 03 morphospecies (Violet) (7, 14\%). In researches carried out in caatinga, T. glaucocarpa (Pereira et al. 2001, 2002) and C. blanchetianus (Barbosa et al. 2012, Rodal et al. 2008) were among the six species with the largest number of individuals. According to Rodal (1992) and Sampaio (1996), C. blanchetianus has a wide distribution, occurring in most areas of Caatinga studied.

Aspidosperma pyrifolium, Auriculata luetzelburgia and Anadenanthera colubrina were considered rare in the fragment, due to the occurrence of only one individual in the area evaluated. In other studies in the area of caatinga, A. pyrifolium and Anadenanthera colubrina presented values ranging from 04 to 1199 and 05 to 123 individuals respectively (Amorim et al. 2005, Araújo et al. 2012, Rodal et al. 2008, Souza and Medeiros 2013, Queiroz et al. 2006, Pereira et al. 2001, Pereira Júnior et al. 2012).

Among the species available, 21 had fewer than ten individuals in the sampled area, among them, Hymenaea courbaril, Amburana cearensis, Ximenia americana and Mimosa tenuiflora, having been frequently cited by informants studied, for medical use. The limited availability of the species in the area may is related to the frequent use of therapeutic practices and other purposes, thus deserving attention as the conservation of these species.

For the Importance Value Index (IVI) species that have obtained the highest values were $T$. glaucocarpa (83.15), 03 morphospecies (Violet) (23.72) and C. blanchetianus (21.34) also have the highest values Relative Density (RD), Relative Dominance (RDO) and Relative Frequency (RF) (Table II). Studies in other areas of caatinga also cited T. glaucocarpa (Pereira et al. 2001, 2002) and C. blanchetianus (Barbosa et al. 2012, Ribeiro et al. 2013) with higher values of IVI.

Among the medicinal species, 35 were not available in the area, some as Myracrodruon urundeuva, Cereus jamacaru, Passiflora cincinnata and Hybanthus ipecacuanha got the most nominations in ethnobotanical survey. Although these species are not available, the use of their relationship in the local community can still be recurring, because according to Torre-Cuadros and Islebe (2003), not all plants are used related to their availability, often acquired in other ways and in other environments.

According to Andrade et al. (2005) and Albuquerque et al. (2011), M. urundeuva is among the ten most important in phytosociological studies in northeastern Brazil, is most commonly found in protected areas, private and well maintained and hardly emerging in anthropogenic environments, which can be justified by their widespread use. According to Nunes et al. (2008), the unavailability of $M$. urundeuva perhaps related to an intense process of predatory exploitation, causing the devastation of their natural populations.

\section{MEDICINAL SPECIES WITH PRIORITY OF CONSERVATION}

Among all of the 28 species available, seven of them had medicinal use in the studied community and have associated timber use. For the same applied to the conservation priority score (CP) (Table III). Among them, six have bound to use perennial structures (bark, inner bark and roots), while a (Bauhinia cheilantha) using only overhead structures (Table SI). The collection of perennial structures of plants can affect the regenerative process of the species when it comes to clear them from the environment (Oliveira et al. 2007, Albuquerque et al. 2011, Júnior et al. 2011). According Albuquerque et al. (2010), the use 
TABLE III

List of species indicated with local conservation priority in the vegetation of caatinga in Milagres-CE.

\begin{tabular}{ccccccccccc}
\hline SPECIES & $\begin{array}{c}\text { No OF } \\
\text { CITATIONS }\end{array}$ & BS & H & IL & V & U & RU & CP & CATG \\
\hline Amburana cearensis & 6 & 100 & 7 & 1 & 3 & 2 & 45 & 82.5 & 1 \\
Hymenaea courbaril & 9 & 100 & 7 & 1 & 7 & 4 & 55 & 87.5 & 1 \\
Mimosa tenuiflora & 5 & 100 & 7 & 1 & 10 & 5.5 & 62.5 & 91.25 & 1 \\
Ximenia americana & 6 & 100 & 7 & 1 & 4 & 2.5 & 47.5 & 83.75 & 1 \\
Bauhinia cheilantha & 4 & 40 & 4 & 1 & 4 & 2.5 & 32.5 & 46.25 & 3 \\
Croton blanchetianus & 6 & 10 & 7 & 4 & 10 & 7 & 70 & 50 & 3 \\
Pityrocarpa moniliformis & 1 & 10 & 7 & 1 & 1 & 1 & 40 & 35 & 3 \\
\hline
\end{tabular}

BS: Biological scores; H: Risk of collection; IL: Local importance; V: Use of diversity; U: value of use; RU: Risk of using; CP: Conservation priority; CATG: Categories; Category 1: with value $>80 \%$; Category 2: value between 60 and 80 ; Category 3: Value $<60$.

of non-perennial structures is considered a less harmful activity to the species.

In the medicinal available species, Mimosa tenuiflora ( $\mathrm{CP}=91.25)$, Hymenaea courbaril $(\mathrm{CP}=87.5)$, Ximenia americana $(\mathrm{CP}=83.75)$ and Amburana cearensis $(\mathrm{CP}=82.5)$ require high priority conservation (CP) and are included in category 1 (scores $>80$ ) indicating that the collection of these species may present a risk of local extinction. All species in this category are not readily available in the art $(\mathrm{DR}=0 \leq 1)$, cited by less than $25 \%$ of the local responders $(\mathrm{L}=$ 1). M. tenuiflora is among the species that have great importance in the field of caatinga in the northeastern semi-arid region (Souza and Rodal 2010). In its natural habitat has been exploited for the production of poles and firewood, and also considered one of the important component of goat diet, sheep and cattle, especially grazing younger sprouts at the beginning of the rains, as well as dried leaves and pods during the period dry season (Pereira Filho et al. 2005).

Hymenaea courbaril has great economic and medicinal importance, with wide range of use $(\mathrm{V}=10)$, and was cited by the majority of local informants also a source of income for many communities. Their exploitation is mainly caused by the timber and medicinal use, with the list of endangered species of the Brazilian Institute of
Environment and Renewable Natural Resources (IBAMA 1992).

Ximenia americana and Amburana cearensis are included in the category of extinction risk, and their reported uses for bark and stem bark, which may use affects them negatively as well as the people who depend on these natural subsidies. These species are widely used in health care within the northeastern communities, often being reported its uses in ethnobotanical studies (Cartaxo et al. 2010, Ribeiro et al. 2014b), mainly linked to perennial structures such as bark and inner bark for own consumption or commercial purpose (Albuquerque and Andrade 2002, Ribeiro et al. 2013).

In category 2 (CP between 60 and 80 ), which are included the species with the potential to be collected according to the location and specific quotas were not registered any kind. Category 3 (value $<60$ ) were grouped three species Croton blanchetianus $(\mathrm{CP}=50)$, Bauhinia cheilantha $(\mathrm{CP}=46.25)$ and Pityrocarpa moniliformis $(\mathrm{CP}$ $=35$ ), being considered appropriate to collect, it is believed that consumption no threat to conservation. C. blanchetianus and P. moniliformis proved widely available in the area (DR $\geq 7$ ). $C$. blanchetianus showed high availability on site, although it had importance for the community $(\mathrm{IL}=4)$ between the evaluated species and a wide 
range of use $(\mathrm{V}=10)$. This species, the study by Ribeiro et al. (2013) is also in the category 3 with a lower priority value $(\mathrm{CP}=40)$ to this work, which shows that their collection at first is not liable. The presence of $P$. moniliformis this category may be associated with its little quote of use and low local importance values (IL), use value (U) and Use of Risk (UK).

Although some species do not appear as priorities to be preserved, most in this area are at risk of collection, being exploited their perennial parts: bark, inbark and roots, a fact that may compromise the conservation of these species, and this form of management improper, possibly already manifested its effects, and may be related to the scarcity of some species of reports before easily found.

According to Albuquerque et al. (2011), estimate priority species for conservation is a useful tool in helping communities to conservation stamp decisions about environmental resources favoring growth studies related to this subject that has risen in ethnobotany literature (Dhar et al. 2000, Dzerefos and Witkowski 2001, Oliveira et al. 2007, Albuquerque et al. 2010, Júnior et al. 2012, Ribeiro et al. 2013).

Ecology and genetics information in natural populations of tropical tree species are incipient in the literature, due to the high diversity and complexity of species, causing difficulties in sampling and in the appropriate methodologies for their study. This knowledge is essential for the understanding of the genetic structure of populations and, therefore, for the design of strategies for conservation, breeding and sustainable management (definition of stock size, adequate management of species, recovery of degraded areas, collection of seeds for planting with native species) (Kageyama et al. 2003).

The pressure on the genetic resources of the caatinga biome is quite pronounced, either due to the socio-economic conditions of the inhabitants or due to the pressure to establish productive activities. The first damage occurs due to the gradual loss of genetic variability for all species of the biome, which may result in a second disappearance of a species under intense use. There have been few studies on the collection, use, characterization, phylogenetic and genetic studies, use of derivatives and pre-improvement of endemic or spontaneous species in the region (EMBRAPA 2000).

Santos et al. (2007) (Amburana cearensis (Fr. Allem.) AC Smith, Myracrodruon urunueva M. Allem., Schinopsis brasiliensis Engl. and Spondias tuberosa) concluded that these species are not uniformly distributed throughout the Brazilian semiarid region, suggesting that the need for a greater number of areas for in situ preservation of the genetic variability of the species studied. Positive relationships between genetic distances and ecogeographic regions have been reported for populations of Amburana cearensis, Myracrodruon urundeuva and Schinopsis brasiliensis (Santos et al. 2007).

Strategies for conservation of genetic resources can be defined based on the information obtained with the DNA markers: when the variability is within the populations, a larger network of environmental preservation areas (APAs) is needed for in situ preservation of genetic variability; when the variability is between the regions, that is, when there is grouping of individuals independently of the collection region, it is indicated that few APAs are necessary (Santos et al. 2007).

\section{CONCLUSIONS}

The study presented a considerable amount of native medicinal species used, showing that the informants are knowledgeable and users of the local flora. However, the low number of medicinal species available and the small number of individuals may be related not only to medicinal or other uses, but also to the gradual loss of genetic 
variability for the biome species, which may result in a second disappearance of a given species under intense use. Strategies that result in establishing a greater number of areas for in situ preservation or sampling of a smaller number of individuals in various landscape units should be considered for $e x$ situ preservation of genetic variability.

Among the species, Mimosa tenuiflora, Hymenaea courbaril, Ximenia americana and Amburana cearensis were considered priority for conservation, since they presented high diversity of use and collection risk. In this way, it is necessary to develop conservation practices of caatinga remnants, seeking improvements in the quality of the biome, and also as a strategy for the recovery of endemic species that would be important for the health of the local communities that use them.

\section{REFERENCES}

ALBUQUERQUE UP AND ANDRADE LHC. 2002. Uso de recursos vegetais da caatinga: o caso do agreste do Estado de Pernambuco (Nordeste do Brasil). Interciência 7(7): 336-346.

ALBUQUERQUE UP, ARAÚJO TAS, RAMOS MA, NASCIMENTO VT, LUCENA RFP, MONTEIRO JM, ALENCAR NL AND ARAÚJO EL. 2009. How ethnobotany can aid biodiversity conservation: reflections on investigations in the semiarid region of NE Brazil. Biodivers Conserv 18: 127-150.

ALBUQUERQUE UP, LUCENA RFP AND LINS-NETO EMF. 2010. Seleção dos participantes da pesquisa. In: Albuquerque UP, Lucena RFP and Cunha LVFC (Eds), Métodos e técnicas na pesquisa etnobiológica e etnoecológica. Recife, NUPEEA, p. 23-37.

ALBUQUERQUE UP, SOLDATI GT, SIEBER SS, MEDEIROS PM, SÁ JC AND SOUZA LC. 2011. Rapid ethnobotanical diagnosis of the Fulni-ô Indigenous lands (NE Brazil): floristic survey and local conservation priorities for medicinal plants. Environ Dev Sustain 13: 277-292.

ALCOFORADO-FILHO FG, SAMPAIO EVSB AND RODAL MJN. 2003. Florística e fitossociologia de um remanescente de vegetação caducifólia espinhosa arbórea em caruaru, Pernambuco. Acta Bot Bras 17(2): 287-303.

ALMEIDA CFCBR AND ALBUQUERQUE UP. 2002. Uso e conservação das plantas e animais medicinais no estado de Pernambuco (Nordeste do Brasil): um estudo de caso. Interciência 27(6): 276-285.
ALMEIDA LS, GAMA JRV, OLIVEIRA FA, CARVALHO JOP, GONÇALVES DCM AND ARAÚJO GC. 2012. Fitossociologia e uso múltiplo de espécies arbóreas em floresta manejada, Comunidade Santo Antônio, município de Santarém, Estado do Pará. Acta Amaz 42(2): 185-194.

AMORIM ILB, SAMPAIO EVS AND ARAÚJO EL. 2005. Flora e estrutura da vegetação arbustivo-arbórea de uma área de caatinga do Seridó, RN, Brasil. Acta Bot Bras 19: 615-623.

ANDRADE LA, LEITE IM, TIBURTINO U AND BRABOSA MR. 2005. Análise da cobertura de duas fitofisionomias de caatinga, com diferentes históricos de uso, no município de São João do Cariri, Estado da Paraíba. Cerne 11(3): 253-262.

ARAÚJO BA, NETO JD, ALVES AS AND ARAÚJO PAA. 2012. Estrutura fitossociológica em uma área de caatinga no Seridó Paraibano. Revista Educ Agrícola Sup 27(1): 25-29.

BARBOSA MD, MARANGON LC, FELICIANO ALP, FREIRE FJ AND DUARTE GMT. 2012. Florística e fitossociologia de espécies arbóreas e arbustivas em uma área de caatinga em Arcoverde, PE, Brasil. Rev Arv 36(5): 851-858.

CARTAXO SL, SOUZA MMA AND ALBUQUERQUE UP. 2010. Medicinal plants with bioprospecting potencial used in semi-arid Northeastern Brazil. J Ethnopharmacol 131: 326-342.

DHAR U, RAWAL RS AND UPRETI J. 2000. Setting priorities for conservation of medicinal plants -a case study in the Indian Himalaya. Conserv Biol 95: 57-65.

DZEREFOS CM AND WITKOWSKI ETF. 2001. Density and potential utilization of medicinal grassland plants from Abe Bailey Nature Reserve, South Africa. Biodivers Conserv 10: 1875-1896.

FIGUEIREDO GM, LEITÃO-FILHO HF AND BEGOSSI A. 1997. Ethnobotany of Atlantic Forest coastal communities: II. diversity of plant uses at Sepetiba Bay (SE Brazil). Human Ecology 25(2): 353-360.

IBAMA - INSTITUTO BRASILEIRO DO MEIO AMBIENTE E DOS RECURSOS NATURAIS RENOVÁVEIS. 1992. Portaria IBAMA n ${ }^{\circ}$ 37-n, de 3 de abril de 1992. <http:// www.ibama.gov.br/flora/extincao.htm $>$ (consultado em: 25 de Setembro, 2013).

IBGE - INSTITUTO BRASILEIRO DE GEOGRAFIA E ESTATÍSTICA. 2010. Cidades@2010.<http://www.ibge. gov.br/cidadesat/link.php?uf=ce $>$. (consultado em: $15 \mathrm{de}$ Junho, 2016).

IPECE - INSTITUTO DE PESQUISA E ESTRATÉGIA ECONÔMICA DO CEARÁ. 2015. Perfil básico municipal. $<$ http://www.ipece.com.br> (consultado em: 05 de Novembro, 2015).

JÚNIOR WSF, LADIO AH AND ALBUQUERQUE UP. 2011. 
Resilience and adaptation in the use of medicinal plants with suspected anti-inflammatory activity in the Brazilian Northeast. J Ethnopharmacol 138: 238-252.

JÚNIOR WSF, SIQUEIRA CFQ AND ALBUQUERQUE UP. 2012. Plant stem bark extractivism in the northeast semiarid region of Brazil: A new aport to utilitarian redundancy model. Evid Based Complementary Altern Med, p. 1-11.

KAGEYAMA PY, SEBBENN AM, RIBAS LA, GANDARA FB, CASTELLEN M, PERECIM MB AND VENCOVSKY R. 2003. Diversidade genética de espécies arbóreas tropicais de diferentes estágios sucessionais por marcadores genéticos. Scientia Forestalis 64: 93-107.

LEAL IR, SILVA JM, TABARELLI M AND LACHER JR TE. 2005. Mudando o curso da conservação da biodiversidade na Caatinga do Nordeste do Brasil. Megadivers 1: 139146.

LÓS DWS, BARROS RP AND NEVES JDS. 2012. Comercialização de plantas medicinais: um estudo etnobotânico nas feiras livres do município de Arapiraca AL. Rev Biol Farm 7(2): 38-51.

MARINHO MGV, SILVA CC AND ANDRADE LHC. 2011. Levantamento etnobotânico de plantas medicinais em área de caatinga no município de São José de Espinharas, Paraíba, Brasil. Rev Bras Plant Med 13(2): 170-182.

MOERMAN DE AND ESTABROOK GF. 2003. Native Americans' choice of species for medicinal use is dependent on plant family: confirmation with metasignificance analysis. J Ethnopharmacol 87(1): 51-59.

MORI SA, BONN BM, CARVALHO AM AND SANTOS TS. 1989. Southern Bahin forests. Bot Rev 49: 155-232.

NUNES YRF, FAGUNDES M, ALMEIDA HS AND VELOSO MDM. 2008. Aspectos ecologicos da aroeira (Myracrodruon urundeuva Allemao- Anacardiaceae): fenologia e germinação de sementes. Rev Arv 32(2): 233243.

OLIVEIRA RLC. 2010. Etnobotânica e plantas medicinais: estratégias de conservação. Bioterra 10(2): 76-82.

OLIVEIRA RLC, LINS NETO EMF, ARAÚJO EL AND ALBUQUERQUE UP. 2007. Conservation priorities and population structure of woody medicinal plants in an area of Caatinga vegetation (Pernambuco State, NE Brazil). Environ Monit Assess 132: 189-206.

PEREIRA FILHO JM, VIEIRA EL, KAMALAK A, SILVA AMA, CEZAR MF AND BEELEN PMG. 2005. Correlacão entre o teor de tanino e a degradabilidade ruminal da matéria seca e proteina bruta do feno de jurema-preta (Mimosa tenuiflora (Willd.) Poiret tratada com hidroxido de sódio. Livestock Research for Rural Development 17(8): 1-9.

PEREIRA IM, ANDRADE LA, COSTA JRM AND DIAS JM. 2001. Regeneração natural em um remanescente de caatinga sob diferentes níveis de perturbação, no Agreste Paraibano. Acta Bot Bras 15(3): 413-426.

PEREIRA IM, ANDRADE LA, MARIA RV, BARBOSA MRV AND SAMPAIO EVSB. 2002. Composição florística e análise fitossociológica do componente arbustivo-arbóreo de um remanescente florestal no agreste paraibano. Acta Bot Bras 16(3): 357-369.

PEREIRA JÚNIOR LR, ANDRADE AP AND ARAÚJO KD. 2012. Composição florística e fitossociológica de um fragmento de caatinga em Monteiro, PB. Holos 6.

QUEIROZ JA, TROVÃO DMBM, OLIVEIRA AB AND OLIVEIRA ECS. 2006. Análise da Estrutura fitossociológica da Serra do Monte, Boqueirão, Paraíba. Bioterra 6(2): 251-259.

RIBEIRO DA, MACÊDO DG, OLIVEIRA LGS, SARAIVA ME, OLIVEIRA SF, SOUZA MMA AND MENEZES IRA. 2014b. Potencial terapêutico e uso de plantas medicinais em uma área de Caatinga no estado do Ceará, nordeste do Brasil. Rev Bras P1 Med 16(4): 912-930.

RIBEIRO DA, MACÊDO MS, ARAÚJO TMS, SILVA MAP, LACERDA SR AND SOUZA MMA. 2013. Prioridade de conservação para espécies medicinais lenhosas em uma área de caatinga, Assaré, Ceará, Brasil. Cad Cult Ciênc 12(1): 46-57.

RIBEIRO DA, OLIVEIRA LGS, MACÊDO DG, MENEZES IRA, COSTA JGM, SILVA AP, LACERDA SR AND SOUZA MMA. 2014a. Promising medicinal plants for bioprospection in a Cerrado area of Chapada do Araripe, Northeastern Brazil. J Ethnopharmacol 155: 1522-1533.

RODAL MJN, COSTA KCC AND SILVA ACBL. 2008. Estrutura da Vegetação Caducifólia Espinhosa (Caatinga) de uma área do sertão central de Pernambuco. Hoehnea 35(2): 209-217.

RODAL MJN, SAMPAIO EVSB AND FIGUERÊDO MA. 1992. Manual sobre métodos florísticos e fitossociológicos. Brasília: Sociedade Botânica do Brasil, 24 p.

ROQUE AA, ROCHA RM AND LOIOLA MIB. 2010. Uso e diversidade de plantas medicinais da Caatinga na comunidade rural de Laginhas, município de Caicó, Rio Grande do Norte (nordeste do Brasil). Rev Bras P1 Med 12(1): 31-42.

SAMPAIO EVSB. 1996. Fitossociologia. In: Sampaio EVSB, Mayo SJ and Barbosa MRV (Eds), Pesquisa Botânica Nordestina: Progresso e perspectiva. Sociedade Botânica do Brasil, Seção Regional de Pernambuco, Recife, p. 203225.

SANTOS CAF, OLIVEIRA VR, KIILL LHP AND SÁ IIS. 2007. Variabilidade genética, com base em marcadores RAPD, de três espécies arbóreas ameaçadas de extinção no Semi-Árido brasileiro. Scientia Forestalis 74: 37-44.

SCHOBER J. 2002. Caatinga: preservação e uso racional do único bioma exclusivamente nacional. In: Notícias do Brasil. Cienc Cult 54(2): 6-7. 
SHAHABUDDIN G AND PRASAD S. 2004. Assessing Ecological Sustainability of Non-Timber Forest Produce Extraction: The Indian Scenario. Conserv Soc 2: 235250.

SHEPHERD GJ. 1995. FITOPAC 1 - Manual do usuário. Campinas: Departamento de Botânica da UNICAMP, 93 p.

SILVA CSP AND PROENÇA CEB. 2008. Uso e disponibilidade de recursos medicinais no município de Ouro Verde de Goiás, GO, Brasil. Acta Bot Bras 22(2): 481-492.

SOUZA CMP, BRANDÃO DO, SILVA MSP, PALMEIRA AC, SIMÕES MOS AND MEDEIROS ACD. 2013. Utilização de Plantas Medicinais com Atividade Antimicrobiana por Usuários do Serviço Público de Saúde em Campina Grande - Paraíba. Rev Bras Pl Med 15(2): 188-193.
SOUZA GF AND MEDEIROS JF. 2013. Fitossociologia e Florística em áreas de caatinga na Microbacia hidrográfica do Riacho Cajazeiras - RN. Geotemas 3(1): 161-176.

SOUZA JAN AND RODAL MJN. 2010. Levantamento florístico em trecho de vegetação riparia de caatinga no Rio Pajeu, Floresta/Pernambuco-Brasil. Rev Caatinga 23(4): 54-62.

TORRE-CUADROS MLA AND ISLEBE GA. 2003. Traditional ecological knowledge and use of vegetation in southeastern Mexico: a case study from Solferino, Quintana Roo. Biodivers Conserv 12: 2455-2476.

\section{SUPPLEMENTARY MATERIAL}

TABLE SI - List of medicinal species recorded in the ethnobotanical survey in the Nazaré Community, City of Milagres-CE. 